\title{
DIFFERENCES OF AGE AND GENDER RELATED POSTURE IN URBAN AND RURAL SCHOOLCHILDREN AGED 7 TO 10
}

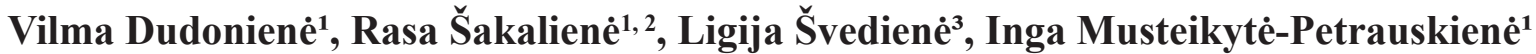 \\ Lithuanian Sports University ${ }^{1}$, Kaunas, Lithuania \\ Lithuanian University of Health Science, Medical Academy², Kaunas, Lithuania \\ Klaipéda University ${ }^{3}$, Klaipéda, Lithuania
}

\begin{abstract}
Research background and hypothesis. Postural disorders appear to be one of the biggest health threats in Lithuania. Especially significant alterations in children's health-related behaviour emerge when they start going to school. These changes in their daily routine are often faulty and may lead to the deteriorating health condition. Postural abnormalities need to be corrected as early as possible before they become permanent. According to some authors, rural children are more physically active compared to city children, therefore it is interesting to identify is there is any difference in body posture in rural and urban schoolchildren.

Research aim was to assess and compare posture in urban and rural schoolchildren aged 7 to 10 .

Research sample: 248 schoolchildren (109 - from urban area; 139 - from rural area).

Research methods. Posture of rural and urban schoolchildren was assessed using W. K. Hoeger's method. Alignment of ten body segments was visually evaluated in a frontal (head, shoulders, spine, hips, knees and ankles) and sagittal (neck and upper back, trunk, abdomen, lower back, legs) planes.

Research results. There were no significant differences $(\mathrm{p}>0.05)$ in total posture score between girls $(41.80 \pm 6.87)$ and boys $(40.62 \pm 7.13)$. Girls and boys from the rural area had significantly $(\mathrm{p}<0.05)$ higher total posture score than their counterparts from the urban area.

Discussion and conclusions. There were no significant differences in total posture score between girls and boys. Regardless of age and gender, schoolchildren from rural area had better posture than children from urban area.
\end{abstract}

Keywords: alignment of body segments, area of residence, children's posture.

\section{INTRODUCTION}

$\mathrm{P}$ osture refers to the body alignment and positioning with respect to the ever-present force of gravity. Good posture entails distributing the force of gravity through the body so no one structure is overstressed. Correct upright posture is considered to be an important indicator of musculoskeletal health (McEvoy, Grimmer, 2005), overall health and well-being. Literature reviews indicate that faulty spinal posture can be correlated to back pain in children (Vidal et al., 2012). Prevention of back pain may be very important because back pain during childhood is known to be a predisposing factor for experiencing back pain into adulthood (Brattberg, 2004).

For children, upright posture measurements might be a useful clinical tool to identify acute spinal postural changes and prevent of potential risk to induce back pain (Hong, Cheung, 2003). Postural analysis is aimed at identifying abnormal deviation from a referenced vertical alignment in the frontal and sagittal planes (Kendal et al., 2005).

Childhood and adolescence are the most important periods in human growth and development. Some authors point out to the 
postural evolution during childhood (age 4-12) as an increase in forward translation displacements of head, shoulders, pelvis and knees in the sagittal plane (Lafond et al., 2007). Especially significant changes in children's health-related behaviour emerge when they start going to school. These changes in their daily routine are often faulty and may lead to deterioration of health conditions. Hence it is necessary that schools should be provided furniture that is fit to the requirement of school children (Shivarti, and Kiran, 2012). Postural control is an important factor in primary schoolchildren. There is a growing public concern about postural alterations found in children and teenagers. According to the information of Lithuanian Health Information Centre, postural disorders appear to be one of the biggest health threats in Lithuania. Reports on children's health status state that postural disorders are diagnosed to almost every fourth of the schoolchildren, while spinal deformity is diagnosed to every tenth of them (Kaušylienė, 2008). Children only seek care when the deformity is visible and therefore represents a serious problem (Nery et al., 2010).

Between the age 7 and 12, a child's posture undergoes a big transformation to reach a compatible balance with the new corporal proportions (Penha et al., 2005). S. McGill (2004) reported that children's modern way of life negatively affects their postural status, especially their lumbar-abdominal region. The influence of the level of urbanization on the place of residence place, and on the biological features of a human, is of an indirect nature (Drzał-Grabiec, Snela, 2012).

The reduction of physical activity, caused by the urban way of life and inadequate exercise in physical education classes, and not being involved in certain sport activities, leads to a weakening of the entire muscular system (Bogdanović, Marković, 2010; Koničanin et al., 2010).

Therefore, we hypothesize that posture of rural children should be better to compare to urban children.

The main aim of the present study was to assess and compare posture in urban and rural schoolchildren aged 7 to 10 .

\section{RESEARCH METHODS}

Design: cross-sectional. Setting: urban and rural schools.

Sample selection. Schoolchildren ranging in age from 7 to 10 years $(n=248$; urban - Kaunas city; $\mathrm{n}=109$; rural - Kaišiadorys district; $\mathrm{n}=139$; boys: $n=116$; girls: $n=132$ ) were invited to participate in the study; two of the schools were in urban areas and two were in rural areas. Schools were chosen based upon their location (rural versus urban). One class from each year level of a different location was chosen to be involved in the study. Written parental consent was obtained prior to the commencement of the study and the study was conducted in accordance with the Declaration of Helsinki.

Anthropometric data. The weight ( $\mathrm{kg})$ and height $(\mathrm{cm})$ of children were taken from the students' medical certificate (No. 027-1/a). Table 1 shows the general characteristics of the present sample. There were no significant differences in body anthropometrics between boys and girls, as well as between rural and urban area children.

Postural Assessment. Evaluation of posture was taken of all pupils who attended classes on a testing day. Posture was evaluated by commonly used clinical assessment technique in the school gymnasium and efforts were made to control for
Table 1. Characteristics of study population

\begin{tabular}{|l|c|c|c|}
\hline \multicolumn{1}{|c|}{$\begin{array}{c}\text { Children's } \\
\text { characteristics }\end{array}$} & $\begin{array}{c}\text { Boys } \\
(\mathbf{n}=\mathbf{1 1 6})\end{array}$ & $\begin{array}{c}\text { Girls } \\
(\mathbf{n}=\mathbf{1 3 2})\end{array}$ & $\begin{array}{c}\text { Total } \\
(\mathbf{n}=\mathbf{2 4 8})\end{array}$ \\
\hline Age $(\bar{x} \pm \mathrm{SD})$ & $9.45 \pm 1.10$ & $9.35 \pm 1.05$ & $9.40 \pm 1.07$ \\
\hline Height $(\bar{x} \pm \mathrm{SD})$ & $134.71 \pm 8.62$ & $134.69 \pm 8.77$ & $134.70 \pm 8.69$ \\
\hline Weight $(\mathrm{kg}, \bar{x} \pm \mathrm{SD})$ & $29.81 \pm 6.00$ & $29.94 \pm 6.60$ & $29.88 \pm 6.30$ \\
\hline BMI $(\bar{x} \pm \mathrm{SD})$ & $16.28 \pm 1.85$ & $16.34 \pm 2.25$ & $16.32 \pm 2.07$ \\
\hline Urban, $\%$ & 49.14 & 39.39 & \\
\hline Rural, \% & 50.86 & 60.61 & \\
\hline
\end{tabular}


temperature, noise and distractions. In an attempt to minimize data collection error, one experienced examiner evaluated children's posture. The examiner was blind to the scope of the study and to the group of the schoolchildren belonged to.

Equipment: plumb line, posture evaluation grid.

For positioning, the child was instructed to stand comfortably barefooted in a normal standing position wearing shorts or swimming trunks between a grid $(160 \times 70 \mathrm{~cm})$ placed on the wall, calibrated into squares $(5 \times 5 \mathrm{~cm})$ and a plumb line suspended overhead. Facing the screen, the plumb line should pass directly up the middle of the back, and from the side, the plumb line should pass through the ear lobe and shoulder joint.

Each child had to look straight ahead without touching either grid or plumb line. Alignment of ten body segments was visually evaluated in a frontal (from the subject's back: head (1), shoulders (2), spine (3), hips (4), knees and ankles (5)) and sagittal (from the subject's left side: neck and upper back (6), trunk (7), abdomen (8), lower back (9), legs (10)) planes (12). The observer was in a $2.8 \mathrm{~m}$ distance from the standing subject.

Each body segment was rated on a scale from one to five with one corresponding to poor body alignment, three - fair, and five - good. A final score was obtained by summing the points given for each body segment and looking at the posture evaluation standards, where more than 45 scores mean excellent posture, between 40-44 - good, 30-39 - average, 20-29 - fair, and less or equal 19 - poor posture (Hoeger, Hoeger, 2010).

Statistical analysis. All data were expressed as a mean (SD) or percentage. Chi-square was used to determine whether there were significant differences in the posture evaluation according to the evaluation standards depending on subjects' gender and residence area. All statistical analysis was performed with Stata 9.0 (at alpha $=0.05)$.

\section{RESEARCH RESULTS}

Posture evaluation. There were no significant differences $(p>0.05)$ in total posture score between girls (41.80 \pm 6.87$)$ and boys (40.62 \pm 7.13$)$. Posture of our subjects can be evaluated as "good" (40-44 of total points). Girls and boys from rural area had significantly $(\mathrm{p}<0.05)$ better posture (higher total scores of posture evaluation) than their counterparts from urban area (Figure 1). Total scores of posture evaluation in rural girls was significantly $(\mathrm{p}<0.05)$ higher than in rural boys (Figure 1).

Posture analysis of separate body segments showed that city girls had significantly $(\mathrm{p}<0.05)$ worse alignment of head, spine, hips, neck and upper back, trunk, abdomen and lower back than rural girls (Figure 2).

Alignment of head, spine, hips, knees and ankles, neck and upper back, trunk, abdomen and lower back in boys from rural area was evaluated by significantly $(\mathrm{p}<0.05)$ higher scores than posture of body segments mentioned above in boys from urban area (Figure 3).

Posture analysis according to pupils' age showed that 7,8 and 10 years old children from rural area had significantly $(\mathrm{p}<0.05)$ higher total posture score than their contemporaries from city area. There was no significant difference in total posture score between 9 years old rural and city children (Figure 4).

The percentage of pupils from urban and rural area who had "poor", "fair", "average", "good" and "excellent" posture is presented in Table 2.

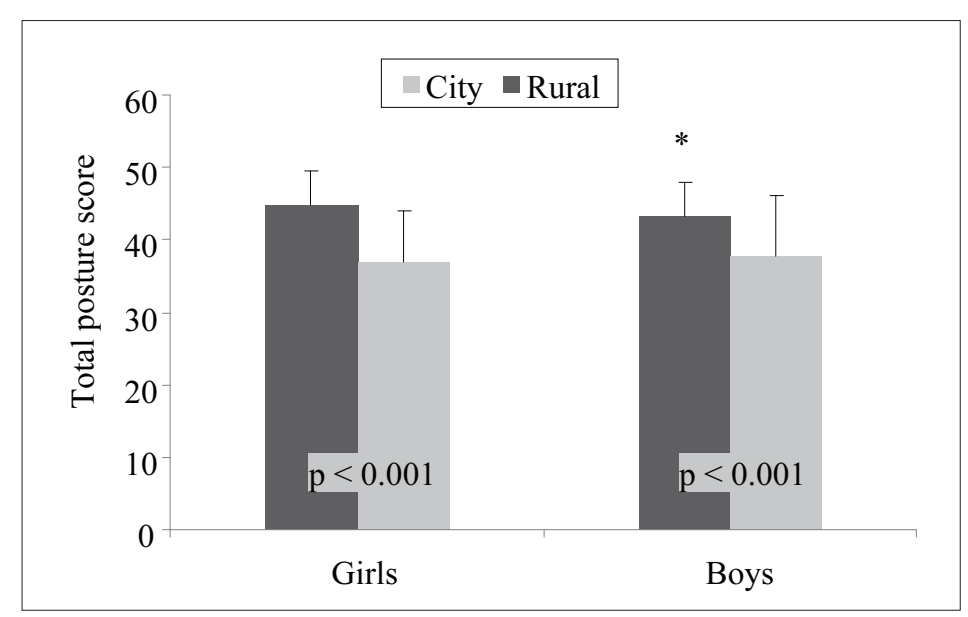

Figure 1. Total posture score in girls and boys according to their area of residence
Note. $*-p<0.05$ compared to total posture scores in rural girls and rural boys. 
Figure 2. Alignment of different body segments in rural and city girls

Note. $*$ - difference between groups is significant ( $\mathrm{p}<0.05) ; 1$ - head, 2 - shoulders, 3 - spine, 4 - hips, 5 - knees and ankles, 6 - neck and upper back, 7 - trunk, 8 - abdomen, 9 - lower back, 10 - legs.

Figure 3. Alignment of different body segments in rural and city boys

Note. $*$ - difference between groups is significant $(\mathrm{p}<0.05) ; 1-$ head, 2 - shoulders, 3 - spine, 4 - hips, 5 - knees and ankles, 6 - neck and upper back, 7 - trunk, 8 - abdomen, 9 - lower back, 10 - legs.

Figure 4. Total posture score in city and rural children aged 7 to 10

Note. $*-p<0.05$ compared to total posture scores in rural and urban schoolchildren.
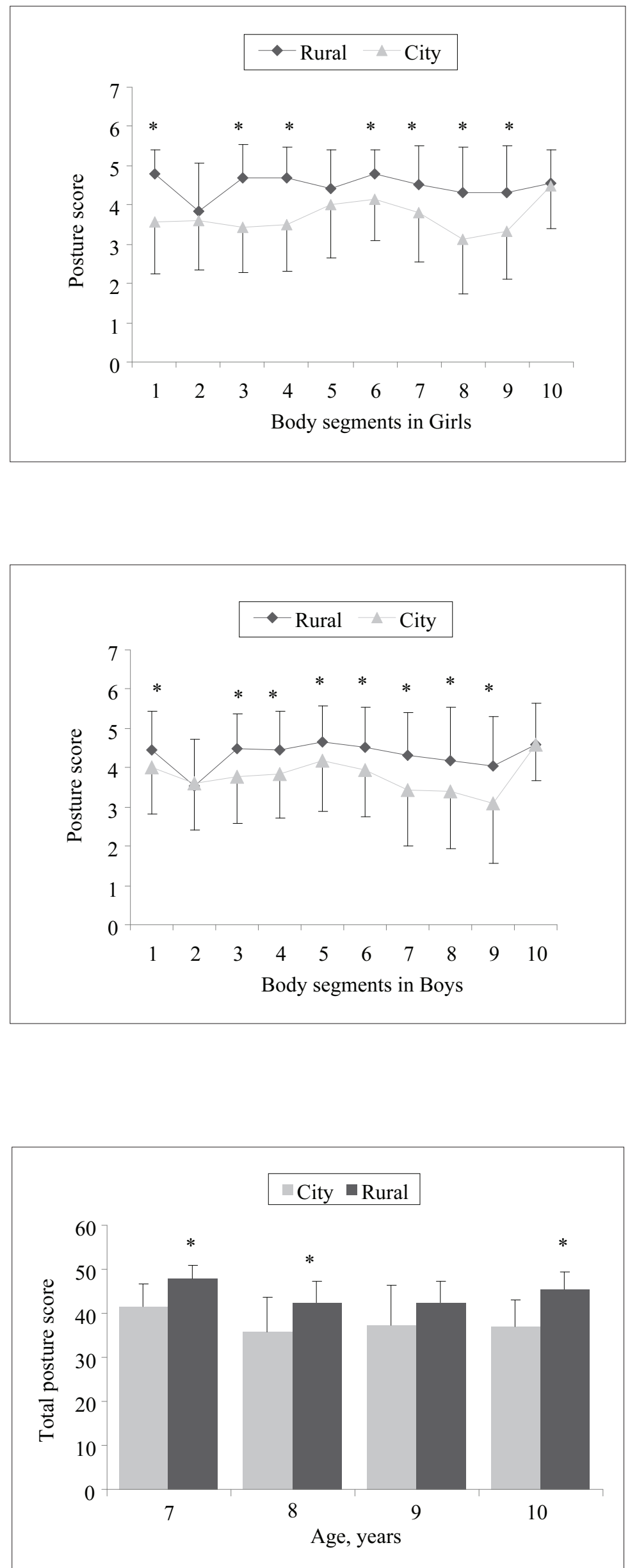


\begin{tabular}{|l|c|c|c|c|c|}
\hline \multirow{2}{*}{\begin{tabular}{c}
\multirow{2}{*}{$\begin{array}{c}\text { Posture } \\
\text { evaluation }\end{array}$} \\
\cline { 2 - 6 }
\end{tabular}} & \multicolumn{4}{|c|}{ Urban } & \multicolumn{2}{c|}{ Rural } & p-value \\
\cline { 2 - 5 } & $\mathbf{n = 1 0 9}$ & $\mathbf{\%}$ & $\mathbf{n}=\mathbf{1 3 9}$ & $\mathbf{\%}$ & \\
\hline Poor & 2 & 1.83 & & & \multirow{2}{*}{0.001} \\
\hline Fair & 21 & 19.27 & 1 & 0.72 & \multirow{2}{*}{} \\
\hline Average & 46 & 42.20 & 30 & 21.58 & \\
\hline Good & 20 & 18.35 & 39 & 28.06 & \\
\hline Excellent & 20 & 18.35 & 69 & 49.64 & \\
\hline
\end{tabular}

\section{DISCUSSION}

The present study evaluated postures of the young population from different areas of Lithuania aged from 7 to 10 years in order to identify postural disorders. The scores of postural assessment showed that posture in girls was very similar to that in boys. It is also important to highlight that some postural disorders like "shoulders", "abdomen", and "low back" were the most prevalent in all children despite gender. A recent study by G. Krutulytè et al. (2007) led to different findings since in that study girls had better posture than boys, but the rates of disorders in separate body segments were similar in both genders. The similarities between the rates of disorders in separate body segments in both genders were also identified in our study; however, the mean scores in participants coming from urban and rural areas were different. Higher mean scores of separate body segments in children from rural area show that their posture is better compared to that of children from urban area. Besides, the posture evaluation showed that shoulder line deformities were most prevalent in children from both areas and in both genders. Our data coincide with S. Tecco et al. (2006) findings who reported that shoulder line deformities were diagnosed for most of the kids aged 8 tol5.

The scores obtained from the posture evaluation of different body segments were summed up and compared with the posture evaluation standards. In this respect, it is important to note that $9.68 \%$ of children had incorrect posture, since their posture was evaluated as "poor" or "fair". With regard to gender distribution, poor posture was determined in $1.7 \%$ of boys, while fair posture was determined in $8.6 \%$ of boys and $9.1 \%$ of girls.
The results of Krutulyte et al. (2007), where the same methodology was used for posture evaluation of children aged 11-12 years, showed the slightly higher percentage of children with poor and fair posture $(24.4 \%)$. There were $2.5 \%$ of boys and $2.5 \%$ of girls with poor posture, while fair posture was determined in $25.6 \%$ of boys and $18.3 \%$ of girls. This might be influenced by growth spurts occurring in 9-12 years olds (Bloomfield et al., 1994), which might cause significant alterations in body shape and might have influence on muscle strength and mobility. All these factors could have influence on kids' postural development (Geldhof et al., 2007). N. Jing et al. (2003) argue that incorrect posture is developed also because of the concomitant trunk bending forward. This might be caused by the increasing weights of backpacks.

According to our findings $35.89 \%$ of children had their posture evaluated as "excellent". It has to be noted that excellent posture was more prevalent in girls $(42.4 \%)$ than boys $(28.45 \%)$. Posture alterations depend on age: older schoolchildren have worse posture than younger once. This is in line with findings from D. Lafond et al. (2007) and further supports the hypothesis of larger postural segmental displacement from the vertical reference in children as they grow and age.

With regard to subjects' area of residence, it was determined that children from urban area had more posture disorders than children from rural area. Poor posture was determined in $1.83 \%$ and fair posture was determined in $19.27 \%$ of children from urban area. In contrast to these results, poor posture was not detected in the group of 
children from rural area at all and fair posture was determined only in one student, comprising $0.72 \%$.

The results of our study demonstrate that rural schoolchildren have better posture than their counterparts from urban area. This could be explained by findings from R. R. Joens-Matre et al. (2008) and J. Dolman et al. (2012) that rural children are more physically active than city children.

\section{CONCLUSION AND PERSPECTIVES}

There were no significant differences in total posture scores between girls and boys. Regardless of age and gender, schoolchildren from rural area had better posture than children from urban area.

\section{REFERENCES}

Bloomfield, J., Ackland, T. R., Elliot, B. C. (1994). Applied Biomechanics and Anatomy in Sport. Melbourne: Blackwell Scientific Publications.

Bogdanović, Z., Marković, Ž. (2010). Presence of lordotic poor posture resulted by absence of sport in primary school children. Acta Kinesiologica, 4 (1), 63-66.

Brattberg, G. (2004). Do pain problems in young school children persist into early adulthood? A 13-year followup. European Journal of Pain, 8 (3), 187-199.

Dollman, J., Maher, C., Olds, T. S. et al. (2012). Physical activity and screen time behaviour in metropolitan, regional and rural adolescents: A cross-sectional study of Australians aged 9-16 years. Journal of Science and Medicine in Sport, 15 (1), 32-37.

Drzał-Grabiec, J., Snela, S. (2012). The influence of rural environment on body posture. Annals of Agricultural and Environmental Medicine, 19 (4), 846-850.

Geldhof, E., Cardon, G., Bourdeaudhuij, I. et al. (2007). Effects of back posture education on elementary schoolchildren's back function. European Spine Journal, $16,829-839$.

Hoeger, W. K., Hoeger, S. A. (2010). Principles and Labs for Fitness \& Wellness. 10-th edition. Wadswordth: Cengage learning.

Hong, Y., Cheung, C. K. (2003). Gait and posture responses to backpack load during level walking in children. Gait Posture, 17 (1), 28-33.

Jing, N., Collaghan, J. P., Tesoo, S. (2003). Prevalence of trunk abnormalities in 10-12 years old children. Journal of Pediatric Orthopaedics, 12, 625-635.

Joens-Matre, R. R., Welk, G. J., Calabro, M. et al. (2008). Rural - urban differences in physical activity, physical fitness, and overweight prevalence of children. The Journal of Rural Health, 24 (1), 49-54.

Kaušyliene, R. (2008). Kas ketvirto moksleivio laikysena - netaisyklinga. Vilnius social health center (VSHC) [2008 05 12]. Internet link: http://www.studijos. lt/moksleiviams/straipsnis/, 05-12-2008.
Kendal, F. P., McCreary, E. K., Provance, P. G. et al. (2005). Muscles: Testing and Function, with Posture and Pain. 15-th ed. Lippincott Williams \& Wilkins.

Koničanin, A., Eminović, F., Bogdanović, Z. (2010). The presence of poor posture kifotic in elementary school, depending on the reason for sport avoiding. Sport Science, 3 (2), 81-84.

Krutulytė, G., Valatkienè, D., Samsonienè, L. et al. (2007). 11-12 metų moksleivių laikysenos vertinimas pagal W. W. K. Hoeger vizualinio laikysenos vertinimo metodiką. Visuomenés sveikata, 36, 16-19.

Lafond, D., Descarreux, M., Normand, C. M., Harrison, D. E. (2007). Postural development in school children: A cross-sectional study. Chiropractic \& Osteopathy, 15, 1-10.

McEvoy, M. P., Grimmer, K. (2005). Reliability of upright posture measurements in primary school children. BMC Musculoskeletal Disorders, 6, 35-45.

McGill, S. (2004). Ultimate Back Fitness and Performance. Waterloo, Ontario, Canada: "Wabundo Publishers".

Nery, L. S., Halpern, R., Nery, P. C. et al. (2010). Prevalence of scoliosis among school students in a town in southern Brazil. Sao Paulo Medical Journal, 128 (2), 69-73.

Penha, P. J., Casarotto, R. A., Sacco, I. C. N. et al. (2005). Postural assessment of girls between 7 and 10 years of age. CLINICS, 60, 9-16.

Shivarti, U., Kiran V. (2012). Design compatibility of classroom furniture in urban and rural preschools. IOSR Journal of Humanities and Social Science, 6 (2), 1-5.

Tecco, S., Caputi, S., Festa, F. (2006). Evaluation of cervical posture following palatal expansion: A 12-month follow-up controlled study. European Spine Journal, 6, 342-346.

Vidal, J., Borràs, P. A., Ponseti F. J. et al. (2012). Effects of a postural education program on school backpack habits related to low back pain in children. European Spine Journal [Epub ahead of print]. 


\title{
MIESTE IR KAIME GYVENANČIŲ 7-10 METŲ VAIKŲ LAIKYSENOS SKIRTUMŲ PRIKLAUSOMUMAS NUO AMŽIAUS IR LYTIES
}

\author{
Vilma Dudonienè1, Rasa Šakalienèi, ${ }^{1}$, Ligija Švediené3 ${ }^{3}$ Inga Musteikytė-Petrauskienè1 \\ Lietuvos sporto universitetas ${ }^{1}$, Kaunas, Lietuva \\ Lietuvos sveikatos mokslu universitetas ${ }^{2}$, Kaunas, Lietuva \\ Klaipédos universitetas ${ }^{3}$, Klaipeda, Lietuva
}

\begin{abstract}
SANTRAUKA
Tyrimo pagrindimas ir hipotezé. Vaikų laikysenos sutrikimai yra viena svarbiausių sveikatos problemų Lietuvoje. Daugiausia pokyčiuc, galinčių sutrikdyti vaikų sveikatą, atsiranda jiems pradejjus lankyti mokyklą. Dienotvarkès pokyčiai dažnai yra kenksmingi ir gali sukelti sveikatos pablogejjimą. Laikysenos sutrikimus reikia koreguoti kaip galima anksčiau, kol jie netampa nuolatiniais. Kai kurių autorių teigimu, kaimo vietovėse gyvenantys vaikai yra fiziškai aktyvesni nei jų bendraamžiai, gyvenantys mieste, todèl įdomu, ar skiriasi mieste ir kaime gyvenančių moksleivių laikysena.

Tikslas - įvertinti ir palyginti mieste ir kaime gyvenančių 7-10 metų vaikų laikyseną.

Metodai. Ivertinta 248 (109 - miesto; 139 - kaimo) jaunesniojo mokyklinio amžiaus vaikų laikysena. Pagal W. K. Hoeger vizualinio laikysenos vertinimo metodiką vertinta 10 kūno segmentų frontalioje (galvos, pečių lanko, stuburo, dubens, kelių ir čiurnos) ir sagitalioje (kaklo ir viršutinès stuburo dalies, liemens, pilvo, apatinės stuburo dalies, kojos) plokštumoje.

Rezultatai. Mergaičiu (41,80 $\pm 6,87)$ ir berniukų $(40,62 \pm 7,13)$ laikysenos suminis balas nesiskyrè $(\mathrm{p}>0,05)$. Kaimo vietovejje gyvenančių berniukų ir mergaičių laikysena buvo įvertinta reikšmingai $(p<0,05)$ aukštesniais balais nei jų bendraamžių, gyvenančių mieste.

Aptarimas ir išvados. Reikšmingų skirtumų tarp bendros mergaičių ir berniukų laikysenos nenustatyta. Kaimo vietovejje gyvenančių vaikų laikysena buvo geresnè nei miesto vaikų nepriklausomai nuo amžiaus ir lyties.
\end{abstract}

Raktažodžiai: kūno segmentai, gyvenamoji vieta, vaikų laikysena.

Gauta 2013 m. sausio 22 d.

Received on January 22, 2013 